\title{
A NOTE ON FEEDING HABITS, ECTOPARASITES AND MEASUREMENTS OF THE BLACIK-BACKED JACKAL CANIS MESOMELAS FROM ADDO ELEPHANT NATIONAL PARK
}

\author{
A. J. HALL-MARTIN and B. P. BOTHA \\ Department of Research and Information \\ National Parks Board of Trustees \\ Private Bag X402, \\ Skukuza \\ 1350
}

Abstract-Data from a small sample of black-backed jackals confined to the National Park indicated that they were opportunistic feeders taking various insects, molluscs, reptiles, birds, mammals and fruits as available. Raiding of ostrich Struthio camelus nests and the probable technique of egg-breaking is also recorded. Body measurements of these jackals fall with the range reported for this species in the Cape Province of South Africa. Observations on age indicate spring or early summer births.

\section{Introduction}

The black-backed jackal Canis mesomelas is a problem animal throughout its range in the Republic of South Africa because of its habit of killing sheep. For this reason its feeding habits have attracted particular attention (Grafton 1965; Bothma 1971; Rowe-Rowe 1975, 1976; Stuart 1977). There is general consensus that it is a highly adaptable opportunist feeder taking carrion, insects, rodents, birds, small game, domestic stock, fruit and reptiles and concentrating on whatever food is locally most easily available.

Most of the material studied has come from farming areas, but some was also collected in conservation areas, notably the material of RoweRowe (1976) from the Drakensberg region of Natal, and Bothma (1966a) from the Kalahari Gemsbok National Park. The present material, although from a small sample of five individuals is of interst because it was collected in the 7735 ha Addo Elephant National Park (AENP), Eastern Cape Province, South Africa to which the jackal population is confined by a jackal proof boundary fence; because jackals are not normally common in densely wooded areas such as the Valley Bushveld (Acocks 1953) which 


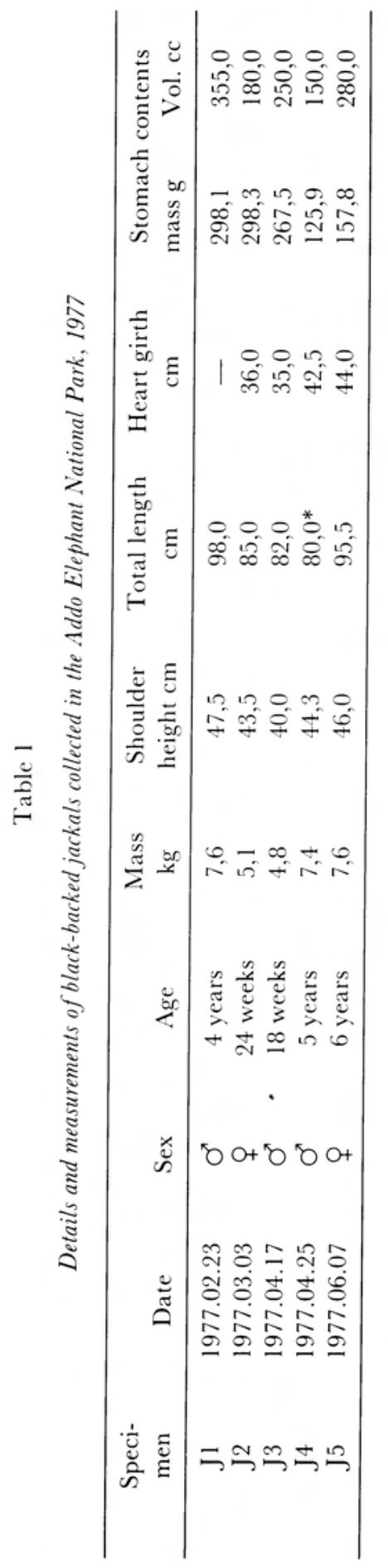


covers more than $95 \%$ of the Park; and because the black-backed jackal has over a period of many years been suspected of being the major predator on the Cape grysbok Raphicerus melanotis and duiker Sylvicapra grimmia in the Park.

\section{Material and Methods}

The five jackals were shot at night in the AENP on various occasions between February and June 1977. The fresh carcasses were superficially inspected for ectoparasites, measured and their mass determined. Stomachs were removed, mass and volume of the contents determined as described by Bothma (1966b). Age determination was done on state of eruption and wear of teeth as described by Lombaard (1971). Chance observations were recorded during other field work in the AENP between May 1976 and March 1979.

Results and Discussion

\section{Body measurements}

Details of age, sex, mass and body measurements of the five animals are given in Table 1. Three of the animals were adult and the measurements of these fall within the range reported for jackals from elsewhere in the Cape Province (Stuart 1977) from much larger samples.

\section{Reproduction}

When the ages of the two immature animals were backdated to their birth dates using body mass at age data given by Lombaard (1971), a rough estimate of month of birth was arrived at. These were September and December respectively. A small jackal pup was seen playing near a den on 8th January when by the behavioural criteria of Lombaard (1971) it would have been between 3 and 9 weeks old. The pup was subjectively assessed as being about 1-2 months old at the time. These indirect estimates all point to a spring or early summer birth period for the blackbacked jackal at Addo which is in agreement with data of Stuart (1977) for other localities in the Cape Province.

\section{Ectoparasites}

Only three species of ticks were collected, the most abundant ( $\bar{X}$ 12,0 $\sigma^{\prime}$ 
$\sigma^{7}$ and 7,2 $q$ per jackal) being Haemaphysalis leachii which was found on all five animals. Two males and one female Rhipicephalus simus were found on $\mathrm{J} 1$; one nymph Amblyomma hebraeum was found on $\mathrm{J} 5$ and three as yet unidentified fleas were found on $\mathrm{J} 2$. A . hebraeum and $R$. simus are commonly found in Addo on other large mammals but this is the first record of $H$. leachii from the Park.

\section{Feeding habits}

The results of the volumetric analysis of jackal stomach contents are given in Table 2. It is striking how important insects are as a source of food at Addo, as compared with their lesser importance elsewhere (Bothma 1971). Insect abundance at the AENP is closely linked to rainfall. Prior to the study period there was a very dry summer with little rain from November 1976 till early February 1977. From 11 th February till the end of the month $138,1 \mathrm{~mm}$ of rain was recorded. There was a rapid response from the herb layer of the vegetation, in particular new green growth of Cynodon dactylon and C. incompletus was abundant within a week. This resulted in a sudden abundance of toktokkie beetles (Psammodes sp.) and the large flightless dung beetle Circellium bacchus. The black-backed jackals were eating large numbers of toktokkies at this time and ignoring the dung beetles (as shown by stomach contents of $\mathrm{J} 1+\mathrm{J} 3$ ). Fruits of Capparis sepiaria were also taken when available (summer months only). The jackals would also eat their fill of termites (J4) when these could be found. During June 1977 there was a widespread outbreak of Spodoptera exigua ("commando worm") in the Eastern Cape and large areas of grazing were lost. Jackals obviously play some role in controlling this pest locally as indicated by the stomach contents of J5 which contained $95,4 \%$ caterpillars.

That the black-backed jackal takes mammal material is evident, but there was no fresh or putrid meat,found to confirm whether the material was hunted or scavenged. Though the hairs were not identified it is certain that they did not come from Cape grysbok or duiker. We could not, from this small sample, draw any conclusions as to the impact which jackals may have on the Cape grysbok whose numbers have remained constant over the past two years, or duiker whose numbers have greatly increased.

Circumstantial evidence of black-backed jackals raiding ostrich Struthio camelus nests has also been found in the Park. At $17 \mathrm{~h} 30$ on 20th March 1977 an ostrich hen on a nest containing 5 eggs was found next to a patrol track. The passing of the vehicle disturbed the bird on the nest and the cock who was close by, and both ran away. The next day the locality was revisited at $08 \mathrm{~h} 30$, no birds were seen and the nest was empty, one egg was lying outside the nest and four heaps of eggshell fragments and egg white were found on the ground and grass near the nest indicating the 
Table 2

Volumetric analysis of the stomach contents of five black-backed jackals from Addo Elephant National Park (February-June 1977)

\begin{tabular}{|c|c|c|c|c|c|}
\hline \multirow[b]{2}{*}{ Item } & \multicolumn{5}{|c|}{ Specimen } \\
\hline & $\mathrm{J} 1$ & $\mathrm{~J} 2$ & $\mathrm{~J} 3$ & $\mathrm{~J} 4$ & $\mathrm{~J} 5$ \\
\hline \multicolumn{6}{|l|}{ Animal food } \\
\hline \multicolumn{6}{|l|}{ Insecta } \\
\hline $\begin{array}{l}\text { Coleoptera: Tenebrionidae: Psammodes sp } \\
\text { Coleoptera: Tenebrionidae: larvae }\end{array}$ & 76,0 & 91,2 & 55,3 & & \\
\hline $\begin{array}{l}\text { Coleoptera: Tenebrionidae: larvae } \\
\text { Coleoptera: Curculionidae: Brachycerus sp }\end{array}$ & 0,8 & & 0,4 & 9,6 & \\
\hline $\begin{array}{l}\text { Coleoptera: Curculionidae: Brachycerus sp } \\
\text { Coleontera: Scarabaeidae: Circellium bacchus }\end{array}$ & & 0,4 & 0,2 & & \\
\hline & & & & 4,0 & \\
\hline Dictyoptera: Blattidae: Cockroaches & & & 1,8 & 1,0 & \\
\hline Isoptera: termite alates & & & & 49,3 & \\
\hline \multicolumn{6}{|l|}{ Hymenoptera: Formicoidea: Streblognathus } \\
\hline mandibularis & & & 0,2 & & \\
\hline Hymenoptera: Formicoidea: unidentified ants & & & & 0,4 & \\
\hline Orthoptera: Acrididae: grasshoppers & & 3,4 & 0,2 & & \\
\hline $\begin{aligned} \text { Lepidoptera: Noctuidae: Spodoptera exigua } \\
\text { (caterpillars) }\end{aligned}$ & & & & & 95,4 \\
\hline Mollusca: Gastropoda: Achatinidae: Achatina sp & & 4,6 & & & \\
\hline \multicolumn{6}{|l|}{ Reptilia } \\
\hline Cryptodira: Testudinidae: tortoise & & & 11,5 & & \\
\hline \multicolumn{6}{|l|}{ Aves } \\
\hline Ratitae: Struthionidae: Struthio camelus (skin) & & & & & 1,4 \\
\hline \multicolumn{6}{|l|}{ Mammalia } \\
\hline Skin & & & 2,3 & & \\
\hline Bone & & & & 8,4 & \\
\hline Hair & & & & 22,0 & \\
\hline \multicolumn{6}{|l|}{ Plant food } \\
\hline \multicolumn{6}{|l|}{$\begin{array}{c}\text { Dicotyledonae: Capparidaceae: Capparis sepiaria } \\
\text { (fruit) }\end{array}$} \\
\hline Monocotyledonae: Poaceae: (grass) & 0,4 & 0,4 & & 2,6 & 3,2 \\
\hline$\therefore \quad$ elephant dung & & & 26,3 & & \\
\hline \multirow{2}{*}{ Unidentified material } & & & & 2,7 & \\
\hline & 100,0 & 100,0 & 100,0 & 100,0 & 100,0 \\
\hline
\end{tabular}

positions where the eggs were broken. Numerous jackal tracks were found in and around the nest. Tracks leading away from the nest area were followed and large fresh ostrich egg fragments, still with egg white inside, were found $60 \mathrm{~m}$ and $200 \mathrm{~m}$ away from the nest, indicating that the jackals had carried these fragments away. We surmise that the jackals at the AENP have perfected a technique of breaking open ostrich eggs by hitting them together in some way. The remaining egg would have been the 'anvil' against which the penultimate egg was broken. Black rangers at the AENP with long field experience tell a similar story. Subsequently three other ostrich nests have been found containing a single egg and broken 
shells of others. It seems likely that these nests were also raided by jackals. A further, possibly related, phenomenon is the large number of solitary ostrich eggs which are regularly found in the Park. During aerial census exercises using a helicopter totals of 42,49 and 42 were counted in 1976, 1978 and 1979 respectively. During the same period many other solitary eggs were collected in the veld. Egg dumping is a known characteristic of ostriches, especially among subordinate hens (Sauer \& Sauer 1966). Only a small part of the Park is suitable ostrich habitat; the relatively high incidence of egg dumping may therefore be related to features of the environment, ostrich population structure and behaviour, and in view of the above observations it is also possible that the nest robbing by jackals may be responsible for at least the occasional solitary ostrich egg.

\section{Acknowledgements}

We thank C. F. Jacot-Guillarmod and F. W. Gess for their identification of insects, and Y. Rechav for identifying ticks. We are also grateful to D. Bower for his assistance in the field.

\section{REFERENCES}

ACOCKS, J. P. H. 1953. Veld types of South Africa. Mem bot. Surv. S.Afr. 28:1-192.

BOTHMA, J. DU P. 1966a. Notes on the stomach contents of certain carnivora (Mammalia) from the Kalahari Gemsbok Park. Koedoe 9:37-39.

BOTHMA, J. DU P. 1966b. Food of the silver fox Vulpes chama. Zool. Afr. 2:205-219.

BOTHMA, J. DU P. 1971. Food of Canis mesomelas in South Africa. Zool. Afr. 6:195-204.

GRAFTON, R. N. 1965. Food of the black-backed jackal: a preliminary report. Zool. afr. 1:41-53.

LOMBAARD, L. J. 1971. Age determination and growth curves in the black-backed jackal, Canis mesomelas Schreber, 1775 (Carnivora: Canidae). Ann Transv. Mus. 27: 135-169.

ROWE-ROWE, D.T. 1975. Predation by black-backed jackals in a sheep farming region of Natal. J. South Afr. Wildl. Manage. Assoc. 5:79-81.

ROWE-ROWE, D. T. 1976. Food of the black-backed jackal in nature conservation and farming areas in Natal. E. Afr. Wildl. J. 14:345-348.

SAUER E. G. and SAUER, F. E. 1966. The behaviour and ecology of the South African ostrich. Living Birds: 45-75.

STUART, C. T. 1977. The distribution, status, feeding habits and reproduction of carnivores of the Cape Province: First progress report. Research Report: Mammals: 1977, Department of Nature and Environmental Conservation, C.P.A. 